\title{
A Comparison of Two Different Types of Vocabulary Treatment: Inclusion or Exclusion of L1?
}

\author{
Sasan Baleghizadeh \\ Department of English Language and Literature, Shahid Beheshti University, G.C., Tehran, Iran \\ Email: sasanbaleghizadeh@yahoo.com \\ Ali Mirzaei \\ Department of English Language and Literature, Allameh Tabataba'i University, Tehran, Iran \\ Email:ama_march@yahoo.com
}

\begin{abstract}
The use of language learners' mother language has traditionally been banned and the potential uses of it still continue to be undermined and neglected. To date, research has not conclusively demonstrated a detrimental effect resulting from use of learners' mother language in foreign language learning classes. On the other hand, there are many studies which have demonstrated the potential power of using the learners' mother language in different areas of foreign language learning. This study examined the possible role of the learners' mother tongue in learning new vocabulary items through a relatively unexplored presentation technique. The results showed the group that learned the words through first language definitions outperformed the group that learned the words through English definitions.
\end{abstract}

Index Terms - vocabulary, mother tongue, word association

\section{INTRODUCTION}

The importance of lexicon and knowledge of lexical items in foreign language learning is quite obvious. Vocabulary plays a central role in the mastery of all four language skills, namely speaking, listening, reading and writing. Research has demonstrated the importance of vocabulary knowledge for language learners in reading (Haynes \& Baker, 1993; Huckin \& Bloch, 1993), speaking (Joe, 1998), listening (Elley, 1989; Ellis, 1994), and writing (Hinkel, 2001; Laufer \& Nation, 1995; Lee, 2003; Walters \& Wolf, 1996).

Among different possible vocabulary treatments, incidental approaches to vocabulary acquisition have been in vogue for quite a long time; however, not many people refer to the role of the learners' first language (L1) in vocabulary acquisition.

The use of the learners' $\mathrm{L} 1$ in foreign language learning has been frowned upon for a long time. It was after questioning the grammar translation method and the beginning of the audio-lingual approach that the rule of "English only" came into prime and it still has its own advocates. Right now in the majority of Iran's English language institutes, the rule of "English only" or "No Farsi" is quite prevalent. This tabooing of the use of the learners' L1 in the process of second language acquisition has spread to all areas of foreign language learning, particularly vocabulary learning. Philipson (1992) has named this prevalent belief the "monolingual tenet" according to which the teaching of English as a second or foreign language should be done entirely through the medium of English. Similarly, Stern (1992) calls this approach toward L1 the "Intralingual Strategy," which refers to the marginalization of the use of L1 in foreign language classes. And, as one can see, this seems to be based on a propagated belief rather than sound theoretical foundations. Although the behavioristic principles behind the audio-lingual method regarded learners' L1 as an interfering factor to be avoided and overcome, the tenets of the communicative approach to language teaching do not prohibit the use of L1 and allow for it whenever it can be helpful (Finocchiaro \& Brumfit, 1983).

Similarly, in the realm of vocabulary such a common belief exists that the learners' L1 is not an appropriate tool for vocabulary learning. Folse (2004) aptly introduces this as one of the myths in second language vocabulary acquisition. Another myth mentioned is that the best dictionary for second language learners is the monolingual dictionary. He appropriately calls these notions myths because they are both widespread and wrong. In both of the above mentioned myths we see the trace of the wrongly held belief that there should be no place for language learners' L1 in vocabulary learning whatsoever. This problem has been the vogue in language learning and still continues to be.

The significance of lexicon

The importance of lexicon in learning a foreign language has recently attracted the attention of scholars more than it did in the past. In the field of linguistics, with the emergence of minimalistic theory and later corpus linguistics, the words and chunks of language, as its building blocks, gained a more important position. In the field of ELT, materials 
writers started preparing materials based on words and chunks as central units of language learning and teaching. Examples of such materials are the lexical syllabus (Willis, 1990), lexical phrases and language teaching (Nattinger \& DeCarrico 1992), and the lexical approach (Lewis 1993). Likewise, Richards and Rodgers (2001) mention a new innovation which has added to the ease of incorporating lexical items into classrooms: advances in computer-based studies of language (referred to as corpus linguistics) have also provided a huge, classroom accessible database for lexically based inquiry and instruction. These studies have focused on collocations of lexical items and multiple word units. A number of lexically-based texts and computer resources have become available to assist in organizing and teaching the lexicon.

Many researchers have worked on the importance of lexical knowledge on different language skills and have found it to be a significant and determining factor. For instance, Zareva, Schwanenflugel and Nikolova (2005) studied the relationship between vocabulary knowledge and general proficiency factor and found some aspects of vocabulary knowledge to be highly related to overall proficiency. They finally suggest that the measures identified as sensitive to capturing the overall state of vocabulary knowledge of learners were also good indexes of language learners' general proficiency.

In the realm of vocabulary acquisition, the state of the art approach has been incidental vocabulary acquisition. For instance, Krashen (1985) refers to extensive reading as a most suitable way of incidental vocabulary acquisition. Other researchers have expressed more or less the same view. Ellis and He (1999) discuss the possible effects of input and output on the incidental acquisition of lexical items. Gardner (2004) lays emphasis on the role of extensive reading on incidental vocabulary acquisition. Paribakht and Wesche (1999) maintain incidental vocabulary acquisition through reading thematically related topics. Rott (1999) investigates the effect of exposure frequency on incidental vocabulary learning and retention through reading and finds a significant relationship between exposure and vocabulary acquisition. However, researchers have voiced disagreement regarding incidental vocabulary learning, too. For example, Gass (1999) has argued against the notion of "incidental" and argues that it is not an easy job to define what incidental means or whether the type of learning experience that the learners are having is really incidental, if by incidental one means that the learner' attention is not drawn to the lexical item. Elsewhere, Huckin and Coady (1999) review the related literature on incidental vocabulary acquisition and raise several unresolved questions about this concept and sum up by concluding that research findings about incidental vocabulary acquisition are yet inconclusive.

Inasmuch as the importance of knowledge of lexicon is not deniable in the overall proficiency of language learners and its profound importance is agreed upon, the search for a more efficient way of vocabulary acquisition has always been continuing throughout the history of foreign language learning. Yet because of the traditional tabooing of native language use in language learning the potential use of the learners' L1 in the process of learning a foreign language has been neglected.

As indicated earlier, the use of the learners' L1 particularly in vocabulary acquisition has not been investigated seriously as an option. Rather, it has been undermined and disdained as either an interfering factor or otherwise harmful device.

In the present study, the researchers have used a new approach in putting the native language of the learners to use for the acquisition of lexical items of the second language. The researchers did not provide the learners with simple word lists as commonly known and used by many. The words were given with their explanations instead of simply giving their synonyms in the learners' mother tongue. The researchers believe this is significant in several respects, some of which are discussed below:

The problem of synonymy: the fact is that one can seldom find an exact synonym for a given word either in the same language or in another language. The Oxford Advanced Learner's Dictionary provides the meaning of words in form of sentences and explanations and avoids giving synonyms for words even as supplementary for explanations because it is believed that complete synonymy does not exist between any two words; by the same token, it can be claimed that one had better clarify the meaning of the words in another language in the form of explanations instead of giving translations which are believed to be the synonyms of that word in that language. It has been argued that any concept can be explained in any language though not necessarily through words. As Wardhaugh (1976) put it, "It appears possible to talk about anything in any language provided the speaker is willing to use some degree of circumlocution" (p. 74).

The problem of wrong associations: any word in any language is ordinarily associated with some other words which appear with it in different contexts. This is also referred to as collocation of words or syntagmatic relations. The problem with giving synonyms for words in this regard is that the assumed synonym or the translation of the word in another language may not have the same word associations and collocations. Therefore, equating a word in one language with a closely related word in another may lead the learner to create wrong associations for the word and this in turn causes problems in subsequent production of the given word. On the other hand, using explanations for making the words understood for the learners can safely avoid such a problem since it just gives the underlying concept of the word to the learners and does not equate it with any false equivalents the in learners' mother tongue.

The problem of production slowing: learning vocabulary items through using bilingual word lists has not been a very good experience. It is said that when students learn the meaning of words by associating them with their L1 equivalents (i.e. through bilingual word lists), they will always have to depend on remembering the native language 
word translation at the time of comprehension and production as a prerequisite, and this can slow the process of comprehension and especially production to a considerable extent (second researcher's personal communication with several EFL teachers). This is not expected to be the problem when explanations replace single words since the underlying concept of a word is given in the form of a sentence or a clause and not in the form of a word to be associated with the newly learned word forever and based on Ausubel's (1968) Obliterative Forgetting, the message itself (in this case the meaning explanation) is expected to be forgotten after some time while the information (the meaning of the word in this case) is retained by the brain.

Given the above problems, the purpose of the present study is to investigate the potential power of language learners' L1 as a source of help and a constructing factor for acquisition of foreign language lexical items. Thus, the study is guided by the following research questions:

1- Is there any difference between learning the meaning and form of the lexical items through English explanations versus Persian explanations?

2- Is there any difference between the long-term retention of lexical items learned through English and those learned through Persian?

\section{METHODOLOGY}

\section{A. Participants}

The participants for this study were 42 EFL intermediate students (both male and female) who were selected on the basis of not knowing the target words and later tested in the study. The participants, whose age ranged from 18 to 35 , were taking a general English course at Zaban Negar Institute in Tehran, Iran.

\section{B. Instrumentation}

The major instrument used in this study was the vocabulary test given to the students in both pretest and posttest. The test, including 20 vocabulary items selected for the purpose of the study, followed the VKS scale. This scale was developed by Wesche and Paribakht (1996) and tests both receptive and productive knowledge of vocabulary. The knowledge of each vocabulary item can be scored from 1 to 5 in the following format:

1. I don't remember having seen this word before.

2. I have seen this word before, but I don't know what it means.

3. I have seen this word before, and I think it means ........ (Synonym or translation)

4. I know this word, and it means ......... (Synonym or translation)

5. I can use this word in a sentence: ............... (If you do this section, please also do section IV.)

The other instruments were the vocabulary lessons prepared by the second researcher and made available in print for both groups, one of which with the target words accompanied by English explanations taken from Oxford Advanced Learner's Dictionary and the other with the same words accompanied by the same explanations translated into Persian by the second researcher and approved by the first researcher. There were two lessons prepared, each consisting of 10 words.

\section{Procedure}

Twenty vocabulary items were selected and presented to the students who participated in the study. Among those students who received the lowest scores on the pretest, 42 intermediate students were selected for the study and were randomly assigned to either of the two experimental groups.

One of the groups received the list of the target words accompanied by explanations from a monolingual English dictionary, and the other group received the words with the same explanations in their native language, i.e. Persian (see Appendices A and B). The first group was called the English explanation group (EEG) and the second the Persian explanation group (PEG). A list of ten words was given to the students in each of the two treatment sessions. The English explanations were extracted from a monolingual dictionary (Oxford Advanced Learner's Dictionary) and the Persian explanations were the same sentences translated into Persian. The follow up examples were provided for both groups. After the two treatment sessions, a posttest containing the taught words was given to both groups and their knowledge of the given words was taken as a measure of the efficiency of the treatment for each group.

\section{Data Collection}

The data used in this study came from the results of the vocabulary test given to the students serving as both the pretest and the posttest. As mentioned previously, the test was based on the VKS scale. There were 20 vocabulary items on the test, each having a score ranging from 1 to 5. Therefore, the test had a maximum score of 100. Needless to say, each student took the same test twice as the pretest and the posttest.

\section{E. Data Analysis}

A $t$-test was run between the posttest scores of the two groups after the data collection in order to see if there was any significant difference between the performances of the English and Persian groups in terms of vocabulary learning. There did not need to be any comparison between the pretest scores of the two groups or between the pretest and 
posttest scores of each group because the participants were selected on the basis of having little or no familiarity with the target words. Therefore, their scores on the pretest turned out to be very low.

\section{RESULTS}

The posttest was administered as planned after the two treatment sessions. Each participant's score was calculated out of 100 and a $t$-test was employed to compare the mean scores of the two groups and look for any significant differences. The descriptive statistics related to the analysis of the results are displayed in Table 1.

TABLE 1.

DESCRIPTIVE STATISTICS FOR BOTH GROUPS

\begin{tabular}{llll}
\hline Groups & $\mathrm{n}$ & $\mathrm{M}$ & $\mathrm{SD}$ \\
\hline EEG & 21 & 45.71 & 14.51 \\
PEG & 21 & 55.09 & 1.356 \\
\hline
\end{tabular}

The results obtained from the $t$-test revealed that the mean score of the PEG group (55.09) is significantly higher than the mean score for the EEG group (45.71), $t(40)=2.16, p=.03$. This suggests that the instructions given to the PEG group were more effective and practically more successful.

\section{DISCUSSION}

As mentioned above, the PEG outperformed the EEG on the posttest. This can be due to several reasons and is congruent with the findings of other studies (Celik, 2003; Ramachandran \& Abdul Rahim, 2004; Rott, Williams \& Cameron, 2002) as well as expectations raised by the literature on the possible role of L1 in language learning in general.

One important reason is the ambiguity which low proficient students face when reading the English explanations of word meanings. This ambiguity is virtually zero in the case of Persian explanations, since all the students have a high level of proficiency in their mother language.

The other issue is the limitations that exist on the explanation of concepts in English. The writers of monolingual English dictionaries need to stick to a limited number of words (defining vocabulary) to be able to assume that understanding the explanations will be possible for students, though as stated above, with some degree of ambiguity. This, however, does not need to be the case with Persian explanations due to the high proficiency of the learners which was mentioned above. This was a fact that the researchers came across while trying to translate the word definitions into Persian.

The other advantage that one could assume for the use of Persian explanations is that they are expected to be easier for the learners to learn or memorize. Although some readers may object to this, it should be noted that a second language learner with limited level of proficiency in the second language could easily claim that memorizing two statements of the same length, complexity and difficulty is certainly harder in a language at which one has a more limited proficiency.

One might claim that there is one big advantage in learning new words through using a monolingual dictionary as it exposes learners to a large amount of extra input in the form of word definitions that they have to read. This input, however, will be absent if the definitions are given in the learners' mother tongue (i.e. use of bilingual word lists or dictionaries). Although this is a remarkable criticism, one could see how much better it would be for the learner to learn the concept and the meaning of the word more concisely and efficiently and then go about receiving extensive input through other sources since the process of reading has been facilitated by clear knowledge of words. Otherwise, they could keep struggling with the meaning of words whenever they see them inasmuch as they have not learnt them well in the first place.

Therefore, the researchers recommend the use of language learners' mother tongue (especially in the form of word definitions instead of synonyms) in the process of language teaching in general and vocabulary learning in particular. This is feasible for classes where the learners share the same first language since the implementation of this strategy in ESL contexts where students might have different mother tongues would be very hard if not impossible; however, in situations like what we have in Iran, it is hard to find a reason for all the negligence that has ever existed about the potential uses of learners' first language.

\section{CONCLUSION}

It seems that despite the bulk of studies that have demonstrated a potentially useful role for language learners' L1 in the process of learning a foreign language, there is still an unannounced consensus on the "harmful" presence of language learners' mother tongue in foreign language leaning. Although making use of learners' L1 is very difficult, even impossible, in classes where learners come from differing first language backgrounds, good use of learners' L1 could be practical in classes with students who share the same L1, as is the case in our native country, Iran. 
The results of this study demonstrate the potential positive effect of using learners' L1 in vocabulary treatment in the form of word lists with Persian definitions. Moreover, further research is needed to shed light on the long term retention of acquired words through this technique since the researchers did not have a chance to examine this aspect of vocabulary learning through this technique. It seems that more constructive roles can be determined for learners' L1 in other areas of language learning as well and teachers and learners need to stop viewing the learners' L1 simply as an interfering factor.

While the findings of this study might be of interest to the advocates of using L1 in their English classes, it should be noted that this study was not faultless and suffers from a number of limitations, the most important of which is lack of a comparison group against which to compare the outcomes of the two vocabulary learning conditions in the present study.

\section{APPENDIX A. A SAMPLE LESSON OF THE ENGLISH GROUP}

Process (n.): a series of things that are done in order to achieve a particular result

To begin the difficult process of educational reforming

So-called (adj.): used to show that you do not think that the word or phrase that is being used to describe sb/sth is appropriate

The opinion of a so-called 'expert'

Productive (adj.): Doing or achieving a lot

A productive meeting

Involvement (n.): The act of taking part in sth

US involvement in European wars

Feature (n.): something important, interesting or typical of a place or thing

An interesting feature of the city is the old market

Determined (adj.): Very certain that you will do sth

She is determined to win the match

Conservative (adj.): opposed to great or sudden social change, showing that you prefer traditional styles and values

The conservative views of his parents

Grateful (adj.): Feeling or showing thanks because sb has done sth kind for you or has done as you asked

I am Extremely Grateful to all teachers for their help

Chairman (n.): a man in charge of a meeting, who tells people when they can speak, etc

Sir Herbert took it upon himself to act as chairman

\section{APPENDIX B. A SAMPLE LESSON OF THE PERSIAN GROUP}

Process (n.): يكى سرى اقدامات كه بر اى دسنيابى به هدف خاصى صورت مى بذيرد

To begin the difficult process of educational reforming.

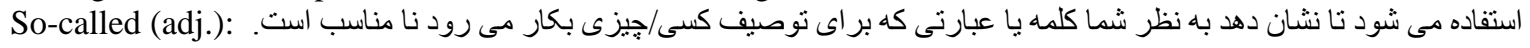

The opinion of a so-called 'expert'

Productive (adj.): بسيار نتيجه بخش يا دار ای دستاورد هاى مطلوب

A productive meeting

Involvement (n.): دركيرى يا مشاركت داشتن در روند يا فر ايندى

US involvement in European wars

Feature (n.): مشخصه ى مهم، جالب يا معرف مكانى يا جيز

An interesting feature of the city is the old market

Determined (adj.): دار ای عزم راسخ وار اده استوار براى انجام كارى

She is determined to win the match

Conservative (adj.): مخالف با تغييرات بزرى يا سريع اجتماع، به علت ترجيح سبكهاو ارزشهاى سنتى از سوى شما

The conservative views of his parents

Grateful (adj.): متشكر يا قدردان به علت اين كه كسى به شما لطفى كرده يا كارى را بر ايتان انجام داده

I am Extremely Grateful to all teachers for their help

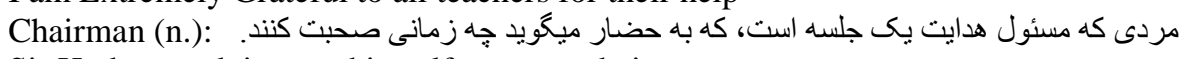

Sir Herbert took it upon himself to act as chairman

\section{REFERENCES}

[1] Ausubel, D. (1968). Educational psychology: A cognitive view. New York: W. H. Freeman.

[2] Celik, M. (2003). Teaching vocabulary through code-mixing. ELT Journal, 5, 361-369.

[3] Elley, W. (1989). Vocabulary acquisition from listening to stories. Reading Research Quarterly, 24, 174-187.

[4] Ellis, R. (1994). Factors in the incidental acquisition of second language vocabulary from oral input: A review essay. Applied Language Learning, 5, 1-32. 
[5] Ellis, R. \& He, X. (1999). The roles of modified input and output in the incidental acquisition of word meanings. Studies in Second Language Acquisition, 21, 285-301.

[6] Finocchiaro M. \& Brumfit C. (1983). The functional notional approach: From theory to practice. New York: Oxford University Press.

[7] Folse, K. S. (2004). Vocabulary myths: Applying second language research to classroom teaching. Ann Arbor: University of Michigan Press.

[8] Gardner, D. (2004). Vocabulary input through extensive reading: A comparison of words found in children's narrative and expository reading materials. Applied Linguistics, 25, 1-37.

[9] Gass, S. (1999). Incidental vocabulary learning. Studies in Second Language Acquisition, 21, 319-333.

[10] Haynes, M., \& Baker, I. (1993). American and Chinese readers learning from lexical familiarization in English texts. In T. Huckin, M. Haynes \& J. Coady (Eds.), Second language reading and vocabulary acquisition (pp. 130-152). Norwood, NJ: Ablex.

[11] Hinkel, E. (2001). Giving personal examples and telling stories in academic essays. Issues in Applied Linguistics, 12, $149-170$.

[12] Huckin, T., \& Bloch, J. (1993). Strategies for inferring word meaning in context: A cognitive model. In T. Huckin, M. Haynes \& J. Coady (Eds.), Second language reading and vocabulary acquisition, (pp.153-178). Norwood, NJ: Ablex.

[13] Huckin T. \& Coady J. (1999). Incidental vocabulary acquisition in a second language: A review. Studies in Second Language Acquisition, 21, 181-193.

[14] Joe, A. (1998). What effect do text-based tasks promoting generation have on incidental vocabulary acquisition? Applied Linguistics, 19, 357-377.

[15] Krashen, S. (1985). The Input hypothesis. London: Longman.

[16] Laufer, B., \& Nation, P. (1995). Vocabulary size and use: Lexical richness in L2 written production. Applied Linguistics, 16, $307-322$.

[17] Lee, S. (2003). ESL learners' vocabulary use in writing and the effects of explicit vocabulary instruction. System, 31, 537-561.

[18] Lewis, M. (1993). Lexical approach. London: Language Teaching Publications.

[19] Nattinger, J., \& Decarrico, J. (1992). Lexical phrases and language teaching. Oxford: Oxford University Press.

[20] Paribakht, T. S. \& Wesche, M. (1999). Reading and "incidental" L2 vocabulary acquisition. Studies in Second Language Acquisition, 21, 195-224.

[21] Philipson, R. (1992). Linguistic imperialism. Oxford: Oxford University Press.

[22] Ramachandran, S. D. \& Abdul Rahim, H. (2004). Meaning recall and retention: The impact of the translation method on elementary level learners' vocabulary learning. RELC Journal 3, 161-178.

[23] Richards, J. C. \& Rodgers, T. S. (2001). Approaches and methods in language teaching. Cambridge: Cambridge University Press.

[24] Rott, S. (1999). The effect of exposure frequency on intermediate language learners' incidental vocabulary acquisition and retention through reading. Studies in Second Language Acquisition, 21, 589-619.

[25] Rott, S., Williams, J. \& Cameron R. (2002). The effect of multiple-choice L1 glosses and input-output cycles on lexical acquisition and retention. Language Teaching Research, 6, 183-222.

[26] Stern H. H. (1992). Issues and options in language teaching. Oxford: Oxford University Press.

[27] Walters, J., \& Wolf, Y. (1996). Language awareness in non-native writers: Metalinguistic judgments of need for revision. Language Awareness, 5, 3-25.

[28] Wardhaugh, R. (1976). The contexts of language. Rowley, MA: Newbury House.

[29] Wesche, M., \& Paribakht, T. S. (1996). Assessing second language vocabulary knowledge: Depth versus breadth. The Canadian Modern Language Review, 53, 13-40.

[30] Willis, J. D. (1990). The lexical syllabus. London: Collins COBUILD.

[31] Wode, H. (1999). Incidental vocabulary acquisition in the foreign language classroom. Studies in Second Language Acquisition, $21,243-258$.

[32] Zareva, A., Schwanenflugel, P. \& Nikolova Y. (2005). Relationship between lexical competence and language proficiency. Studies in Second Language Acquisition, 27, 567-595.

Sasan Baleghizadeh is an Assistant Professor of TEFL at Shahid Beheshti University, G.C. of Iran, where he teaches applied linguistics, syllabus design, and materials development. He is the author of a number of simplified readers such as Tales from Rumi and Tales from Men of Wisdom all published by the Iran Language Institute. His recent publications have appeared in ELT Journal, The Teacher Trainer, and Modern English Teacher.

Ali Mirzaei is currently an MA student of TEFL at Allameh Tabataba'i University in Tehran, Iran. He is interested in exploring new techniques of vocabulary presentation to EFL students. 